\title{
Research on the Construction of China's Business English Teaching Staff in Applied Undergraduate Universities
}

\author{
Changlan Lu \\ Shandong University of Finance and Economics, Jinan, Shandong Province, 250001, China \\ *Corresponding author. Email: luchanglan@163.com
}

\begin{abstract}
This article aims to solve the problem of cultivating the qualified business English teacher team in China's applied undergraduate universities. Based on the previous research and the author's personal observation, the author gives the following suggestions: carrying out the internal school-based training, strengthening school-enterprise cooperation, encouraging teachers' self-motivated transformation, making full use of online resources, inviting qualified business English professionals to give lectures, etc. The author thinks all of these measures will help to ensure the training quality of professional business English teachers.
\end{abstract}

Keywords: Business English teaching staff, Quality and status quo, Countermeasures.

\section{INTRODUCTION}

With the continuous deepening of China's opening to the outside world and the strengthening of economic globalization, the country's demand for comprehensive business English professionals who have both strong English language capability and business knowledge continues to increase. In this context, business English major is increasingly becoming a popular discipline, and more and more colleges and universities begin to set it up. In April 2007, Chinese Ministry of Education approved the establishment of the business English major in the undergraduate admissions of colleges and universities. Before 2010, there were 14 colleges and universities with business English undergraduate majors; until 2013, there were already more than 140 universities and independent colleges offering business English undergraduate majors. The question that follows is, what is the status quo of the business English teaching staff in those colleges and universities? Can the existing teacher team meet the needs of business English major development? How to build a team of high-quality business English teachers with a reasonable profession structure? This article will discuss some related issues on the basis of existing research results.

\section{ANALYSIS OF THE QUALITY NEEDS OF BUSINESS ENGLISH TEACHERS FROM THE PERSPECTIVE OF SOCIAL NEEDS AND TALENT TRAINING}

What kind of business English teachers the colleges and universities need depends fundamentally on what kind of business English talents the society needs. Only with precise social needs can we accurately answer the question of what qualities a business English teacher should have.

\subsection{An Analysis of the Quality Needs of Business English Teachers from the Perspective of Social Needs}

The general view is that the society needs the applied, compound and innovative business English talents. Business English professionals must have a solid foundation of English language knowledge and the proficient language use capability, as well as broad business knowledge and business operation skills, strong cross-cultural communication skills and adaptability, and good innovation and entrepreneurship. Regarding this social demand, some researchers believe that "the complexity of business English professional knowledge and applicability of competence requires that the structure of teachers' knowledge and competence 
must be complex and practical" [1]. It is generally believed that business English teachers should have a multi-disciplinary knowledge structure (English and business knowledge background), strong teaching and research capabilities, and a certain degree of practicality.

On the whole, the author agrees with the viewpoint that business English teachers should have a multidisciplinary knowledge structure and strong teaching and research capabilities, but it is necessary to have a further discussion about the meaning of "practicality". When it comes to the practicality of business English teachers, some researchers believe that "the discipline --business English essentially requires professional teachers to have both solid theoretical knowledge and relevant practical experience, ability and some other professional qualities. At the same time, teachers need to have rich practical work experience, high practical skills. They should be familiar with the product information, market dynamics, business operations and trends of the industry they are engaged in" [2]; "They should have a wealth of first-line industry and enterprise work experience and a generous professional knowledge base" [3]. The author believes that the above requirements seem to be too demanding for full-time business English teachers, and it is difficult to meet all the requirements in reality; and from the perspective of "creating a highly simulated business English teaching situation", the above requirements are not necessary to be satisfied.

The author believes that strengthening the schoolenterprise cooperation and joint construction of business English laboratories and internship training bases will help business English teachers to conduct long-term and systematic social surveys in enterprises, and to allow them to participate in the company's activities within the possible extent, which should be a feasible method for the faculty building of business English teachers.

\subsection{Analysis of Business English Teachers' Quality Needs from the Perspective of Talent Cultivation}

Analysis From the perspective of talent cultivation, the training of qualified business English graduates is the result of the overall teamwork of the teaching staff, which includes not only the participation of business English teachers but also of teachers in other subjects. As far as the cultivation of cross-cultural communication skills is concerned, the teaching of foreign politics, society, law, literature, religion and other fields of knowledge may require the cooperation of multiple teachers of different disciplines. It is not necessary at all to require most business English teachers or even all business English teachers to have "practical" or even professional working experience.
It is a truth what colleges and universities aim to cultivate are qualified business English graduates. And it is a bigger truth if a business graduate from any university in the world wants to become a successful business person, he/she must go through a long-term training and continuous re-learning process in actual work. Vocational capability and competence cannot be accomplished at one time in school. What colleges and universities have laid for students are a basic knowledge foundation, a professional literacy foundation, a continuous learning and self-improvement foundation. The specific industries that graduates will go to in the future are very different. Their understanding and familiarity with the specific industry information, product information, market dynamics and other issues must be the goal that they have to achieve only after they have engaged in this specific field of job. It is not necessary for their teachers to "be familiar with all of the product information, market dynamics, business operation and development trend of the industry". Besides, the product information, market dynamics, and business operations are keeping updating. It will really be a big challenge for the teachers to keep track of the latest industry information.

The author believes that the "Undergraduate Teaching Requirements for Business English Majors in Colleges and Universities (Trial)" formulated in 2009 is quite cautious, scientific and feasible in the definition of training objectives, and it does not make too detailed or excessive training objectives. The goals are extremely realistic and achievable.

In summary, from the perspective of social demand and talent training, it is not advisable to have a too narrow or biased understanding of the "practical" quality requirements for business English teachers. "Practical" does not necessarily require teachers to have the front line experience of relevant industries. Business English teachers should have a cross-cutting knowledge structure. And for them, to have strong teaching and research skills are the basic requirements, which should be met to the greatest extent.

\section{ANALYSIS OF THE STATUS QUO AND EXISTING PROBLEMS OF BUSINESS ENGLISH TEACHERS IN CHINA'S COLLEGES AND UNIVERSITIES}

Researchers generally believe that most of the business English teachers have a relatively narrow and single knowledge structure and lack a cross-disciplinary and comprehensive knowledge structure. Their knowledge background is either a single English language and literature one, or a single economic and business one (The teachers of English language and literature account for the majority, and teachers of economics and business background are a minority); teachers with both English and business backgrounds 
are relatively small, and those with a compound knowledge background and professional qualifications are fewer. In addition, a small number of business English teachers are foreign teachers with business education background, some others are foreign students who have completed business education abroad, or guest teachers from companies.

As an independent discipline, we know the establishing of business English major starts late in China, but it develops rapidly, and there is lack of farsighted overall planning and practical strategic layout, all of which has resulted in the continuous overexpansion as well as problems of this discipline. With its expansion, there are many problems arising, one of which is the building problem of the teaching staff of business English in colleges and universities. The majority of business English teachers graduate from a single English language and literature education background. They lack a business education background and have not conducted a more systematic and comprehensive self-study of business knowledge or related training. Due to the flaws in the knowledge structure, most of the business English teachers prefer to take the college English teaching methods to teach business English courses, so it is difficult to achieve ideal teaching results. They are better at explaining vocabulary, grammar, translation skills, and writing methods, but they are not good at how to analyze the business knowledge accurately and how to train students to proficiently use English language skills in a business context. This also makes it difficult for them to construct efficient classroom teaching models and innovative teaching methods. In the article "Research on Strengthening the Construction of Business English Teachers", Yuan Qingrong points out "Due to insufficient business knowledge and the habit of teaching the college English over the years, they tend to teach too much language knowledge in class, and when encountering more professional business questions (such as letters of credit), it is difficult for them to explain these terms clearly and not to say to guide the students to think broadly and critically." [4] In contrast, business English teachers from a single business education experience have sufficient business knowledge themselves. However, most of them have insufficient English language proficiency. Because they are limited by their language proficiency, they use Chinese when teaching in class or expounding business terms to students. It is a bit difficult to require them to use English throughout the teaching process.

As a whole, teachers with a single discipline background (whether from a pure English major or a pure business major) cannot perfectly combine English and business knowledge to achieve efficient teaching results or goals. So, what will happen if asking those English foreign teachers with business education experience to use English to teach business courses to students? The author believes that when offering such courses, both of students' English proficiency and business knowledge foundation should be considered. The teaching topics have to be seriously selected, and teaching content should be carefully designed. Such courses should only be offered to senior students. These courses will help to effectively integrate students' language application ability and business knowledge. Then the students' business skills can be advanced to a whole new level.

\section{COUNTERMEASURES AND SUGGESTIONS FOR THE CONSTRUCTION OF BUSINESS ENGLISH TEACHERS IN COLLEGES AND UNIVERSITIES}

In order to build a high-quality faculty of "doublequalified" business English teachers with reasonable structure and sustainable development, it needs the support of the government's macro policy, of the education and teaching reform, and of the universities and colleges. This section of the article will propose some countermeasures and suggestions in response to the deficiencies in the existing business English teaching staff in China's colleges and universities discussed above.

Regarding the existing teaching team, the author thinks that the most important thing is for colleges and universities to do is to train the existing business English teachers through various channels and methods. How to cultivate the qualified business English teacher team, the author gives following suggestions:

(1) The colleges and universities should make full use of the internal resources and implement schoolbased training. This is a suggestion that most researchers have mentioned. The author believes that this suggestion is very scientific and practical, and it has the advantages of strong operability, sustainability and low cost. School-based training will not delay the teachers' daily teaching and research activities or the school's curriculum arrangements, and meanwhile it can help to improve the professional proficiency of business English teachers. The budgets of many colleges and universities are already very tight. The large-scale sending of teachers to foreign business universities for training is not realistic, many colleges and universities cannot afford the fund, and furthermore it will affect the normal teaching schedule of the school. Of course, when carrying out school-based training, attention should be paid to the scientific planning, systematic arrangements, and careful selecting of courses for teachers who undertake different teaching tasks, so as not to let the training become a mere formality without actual effect. 
(2) Colleges and universities with sufficient financial resources and teaching staff can consider to encourage their teachers to go to well-known domestic universities for further study as visiting scholars, or to get some interdisciplinary master's or higher degrees without delaying normal teaching activities. Although this training method has the disadvantages of costing more money and bringing many inconveniences to the participants of the training, if the university has sufficient funds and the selected candidates have sufficient curiosity and self-motivation, this training method will be a good choice. For many schools, although the cost of school-based training is low, the problem of lack of a strong enough training force does exist. The overall situation of teachers in many schools is not very optimistic. When making this kind of training plan, attention should be paid to strengthen the supervision, inspection and assessment of training participants to avoid spending a great deal of money but with little effect.

(3) The colleges and universities should strengthen the school-enterprise cooperation and co-construction, and jointly establish business English laboratories and practice bases with local business-related enterprises. They can encourage teachers to go deep into the company to conduct long-term and continuous social research to understand the needs of the company for talents, enabling teachers fully understand the actual operating procedures and practices of business activities. And also they can invite the business English practitioners with higher theoretical literacy and rich practical experience to provide their teachers with relatively systematic training. Within the scope allowed by the enterprise, teachers are allowed to participate in the enterprise's daily business activities and do some auxiliary work that does not involve the enterprise's commercial secrets and core business information.

(4) Some colleges and universities can choose to cooperate with well-known domestic universities or international colleges in running schools and establishing inter-school cooperative and friendship relations. According to the actual situation of the school, those who can cooperate in running school should cooperate in running school, and those who can establish a cooperative relationship should establish a cooperative relationship. All in all, it is helpful to invite the outstanding teachers of foreign schools to systematically train the teachers of their own school. The teaching quality of the teachers in this school can also be improved by encouraging their teachers to serve as teaching assistants for outstanding teachers in other schools.

(5) The colleges and universities can make regular invitations for highly qualified business English professionals to come to the school to give a series of academic lectures or seminars. Generally speaking, the business English practitioners of the company are under great pressure at work, they are busy in business, so it is not practical in hiring them as guest teachers, because they do not have so much time and energy to prepare lessons systematically. It is quite difficult for them to systematically teach students a comprehensive subject. However, if the school has carefully designed the teaching topics, the business English practitioners of the company can be invited to come to the school to give some academic lectures and seminars, which will be a relatively preferable approach. The basic knowledge and the more theoretical parts are taught by the teachers of the school, and it is more feasible to invite business English practitioners to undertake the other teaching part that is concerned with business practices.

(6) The colleges and universities can make full use of online resources and encourage the teachers to learn online on a regular basis. The advent of the Internet age has provided new ways and methods for learning and training. Now a lot of world-wide famous schools have launched a number of free online courses. And there are many online courses on business and management. The business English teachers can make good use of these resources, which will surely help them to improve their business literacy and capabilities on the long run.

(7) The colleges and universities can strengthen the contact and cooperation with some well-known software companies. These software companies focus on developing some application soft wares, such as simulation software, teaching software, and examination software, etc. Some of the simulation and teaching software developed by these companies are of great help to current teaching activities. They can simulate various scenarios and processes of some business activities very realistically. With the help of these software, teachers can easily carry out situational teaching, which is very helpful to teachers in reforming their teaching procedures. If these soft wares are fully and properly used, teachers can grasp the actual operation process of international trade, negotiation, logistics and other business activities without much difficulty, which can make up for teachers' regrets of lacking practical experience and weak "practicality".

\section{CONCLUSIONS}

The establishing of business English major and the improvement of the business English talent training are inseparable from qualified and professional business English teachers. However, the current contradiction between the rapid development of business English majors and the lagging construction of business English teachers is difficult to resolve quickly. Regarding the problems existing in the current business English teacher team, it is necessary to strictly refer to the "National Standards for Business English Majors" to 
guide business English teachers to make clear their professional requirements.

The colleges and universities should encourage the business English teachers to transform as soon as possible and carefully formulate their personal career development plans; regularly participate in various business English-related training projects, conferences, workshops and so on to continuously expand their academic vision and teaching capabilities; earnestly incorporate theoretical knowledge of the textbook into practice; strive to introduce high-quality resources such as business-related MOOCs, micro-classes, and quality online courses into the traditional classroom teaching, and constantly try new teaching methods so as to improve the overall professional competence of business English teachers. Only in this way can we meet the needs of the construction of business English majors and the training of applied business English talents.

\section{REFERENCES}

[1] Wang Jun, Hou Tianhao. On How to Strengthen the Construction of the Teaching Staff and Curriculum of Business English Majors in Colleges and Universities [J]. Journal of Jilin Normal University (Humanities and Social Sciences Edition), 2009 (2).

[2] Lu Yanhua, Strategic Research on the Construction of Business English Majors in Normal Universities [J]. Heilongjiang Higher Education Research, 2013 (5).

[3] Ye Zhangyong, Ye Shuangshuang. Business English Professional Teacher Training Based on Constructivism Theory [J]. Journal of Beijing City University, 2010 (5).

[4] Yuan Qingrong, Research on Strengthening the Construction of Business English Teachers [J]. Journal of Changchun University of Science and Technology (Social Science Edition), 2018 (5).

[5] Xue Jinxiang, The Construction of Business English Curriculum System from the Perspective of Ecology [J]. Heilongjiang Higher Education Research, 2018 (2).

[6] Clarice S.C.Chan, Proposing and illustrating a Research-Informed Approach to Curriculum Development for Specific Topics in Business English[J]. English for Specific Purposes, 2018 (10) 